\title{
Innovation, innovation, innovation
}

\author{
The financial crisis teaches us about the consequences of ignoring risks. We cannot afford to repeat the \\ same mistakes for the continuing crises in energy and climate.
}

What a ride 2008 was. Although the sub-prime mortgage market clearly showed reasons for concern, the real news at the beginning of last year was a dramatic surge in oil prices from about $\$ 90$ a barrel to almost $\$ 150$. Suddenly, we had a good preview of how life is going to be if oil reserves are depleted.

In mid-September, however, these problems suddenly seemed irrelevant. What was largely considered a problem confined to the banking sector and housing market turned into a perfect storm when one of Wall Street's powerhouses, Lehman Brothers, was found to be in trouble and the US Treasury refused to bail them out. Fearing that others would also fail, banks became suspicious of each other. The entire inter-bank trading system collapsed and complete meltdown was only prevented by a $\$ 700$ billion rescue package. This accelerated collapse was not only caused by the housing market, but also because huge debts were incurred through the use of complex financial instruments such as credit default swaps, which effectively leveraged the risks from subprime mortgages. These instruments were legalized at the end of 2000, and explicity put beyond any regulatory oversight. Coming from nowhere, the market in these complex financial instruments reached about 50 trillion dollars by the end of 2007 .

Unfortunately, the problems in the financial markets meant that 'real economy', which was already heading for a slowdown, was affected badly as credit lines for businesses dried up. Therefore, there are now plans for a rescue package for the economy as a whole, which may well reach another $\$ 700$ billion. The recession is widely expected to last all of next year, if not longer - an opinion shared by Joseph Michels, a managing director at the private equity fund One Equity Partners, whom we interviewed for this issue ${ }^{1}$.

Unfortunately, the consequences of the recession on scientific research might be dire. There are reports that the University of California needs to cut back $\$ 100$ million in spending ${ }^{2}$, and there are hiring freezes and budget cuts at Cornell and elsewhere ${ }^{3}$.

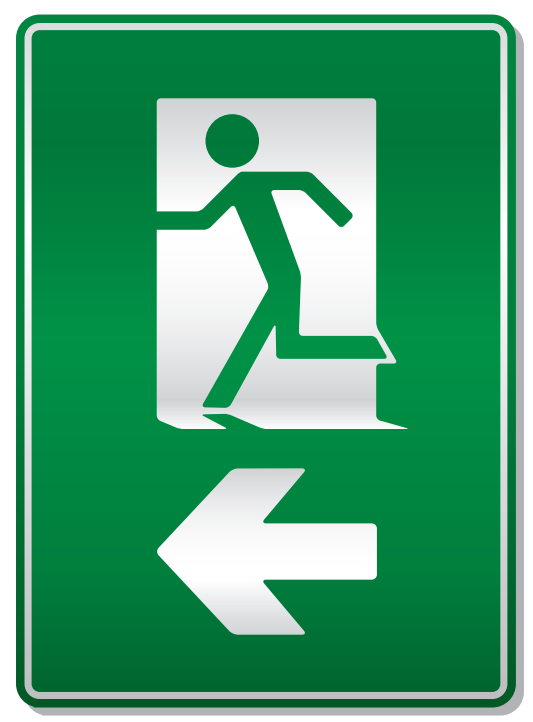

Exit from the crises: Investments in science and technology, such as greener, cleaner forms of energy, can help us overcome the present multiple man-made crises.

Amidst speculations that its $\$ 37$ billion endowment has been hit by losses in the region of $30 \%$, Harvard too has announced a hiring freeze ${ }^{4}$.

At the same time, we cannot afford reductions in fundamental research or to be complacent on issues such as the energy crisis. The lesson from the recent financial meltdown seems straightforward. If we do not understand the risks we are exposed to and cover ourselves against them, the long-term implications might be grim. Unlike the banks and their complex financial instruments, which even proved too complex for sophisticated risk-assessment computer models, the gamble we are taking with our planet is painfully clear. Take the energy crisis as an example. The high oil prices in the first half of 2008 illustrate what happens if we cannot rid ourselves of our addiction to it. Sadly, the response remains woefully inadequate. According to the International Energy Association's World Energy Outlook published in November 2008, output in clean, renewable energies still accounts for only $15 \%$ of global demand ${ }^{5}$. Worse, the study also emphasizes that if we do not act, temperatures may soar by a staggering $6{ }^{\circ} \mathrm{C}$ by the end of the century.

Even though public budgets are badly strained, it is clear that we have to take a long-term approach and cannot afford to reduce our spending on fundamental research. Budget cuts and hiring freezes are anything but a solution. We must equip our academic system with sufficient funds to push ahead fundamental research in areas such as clean energy technologies. To put the financial effort that would be required into perspective, compared with the $\$ 700$ billion rescue package for the banks, the US Department of Energy's Office of Science budget for 2008 was only $\$ 4$ billion, and that of the US National Science Foundation about $\$ 6.5$ billion. Relative to the bank bailout, not much would be needed to address these urgent issues we will all face in the longterm. If on the other hand, we do not invest comparatively moderate figures into sorting out the planet's future, we may well end up paying a bill that dwarfs the amount needed to bring the economy out of recession.

Here, at least one part of Wall Street may be setting a good example. Joseph Michel's private equity fund is heavily investing in the alternative energy sector. Investments such as these point towards the future because they create manufacturing jobs in modern industries, rather than in those in decline.

The energy crisis and global warming may not seem to impact our life as much as the economic crisis. But if we don't act now, we might soon be in a situation where significant costs and serious implications await us. This year will bring a change in US politics that will have an impact on all developed nations. Let's hope that 2009 will mark a turning point, not only for the economy, but also in our approach to science policy and science funding.

\footnotetext{
References

1. Nature Mater. 8, 3-4 (2009).

2. http://www.universityofcalifornia.edu/news/article/19016

3. http://www.nytimes.com/2008/11/08/education/08college.html

4. http://www.boston.com/news/local/breaking_news/2008/11/

harvard_freezes.html

5. http://www.worldenergyoutlook.org/
} 